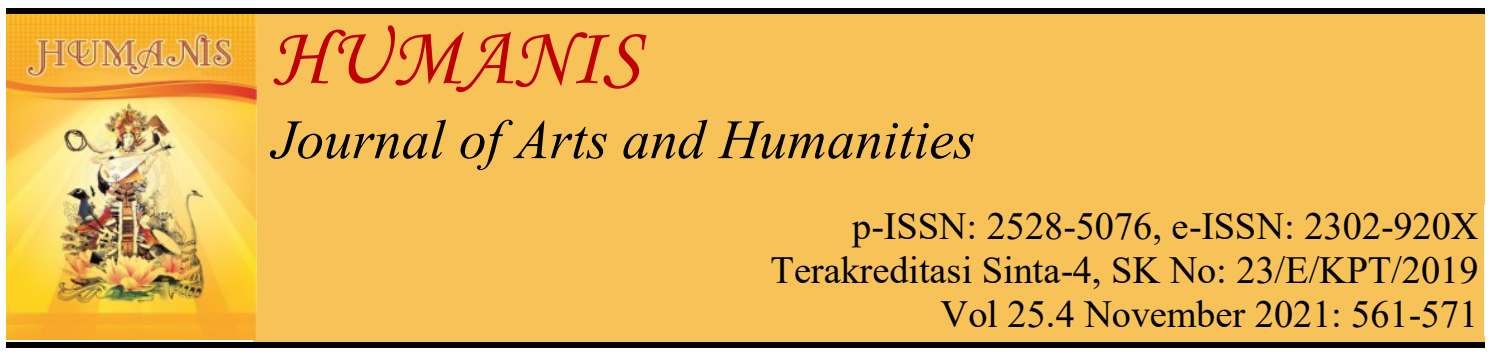

\title{
Antologi Puisi Membaca Lambang Analisis Citra Wilayah Pesisir
}

\author{
Ridwan Andhika Martianto
}

Universitas Udayana Denpasar, Bali, Indonesia

Email korespondensi: ridwanandhika98@,gmail.com

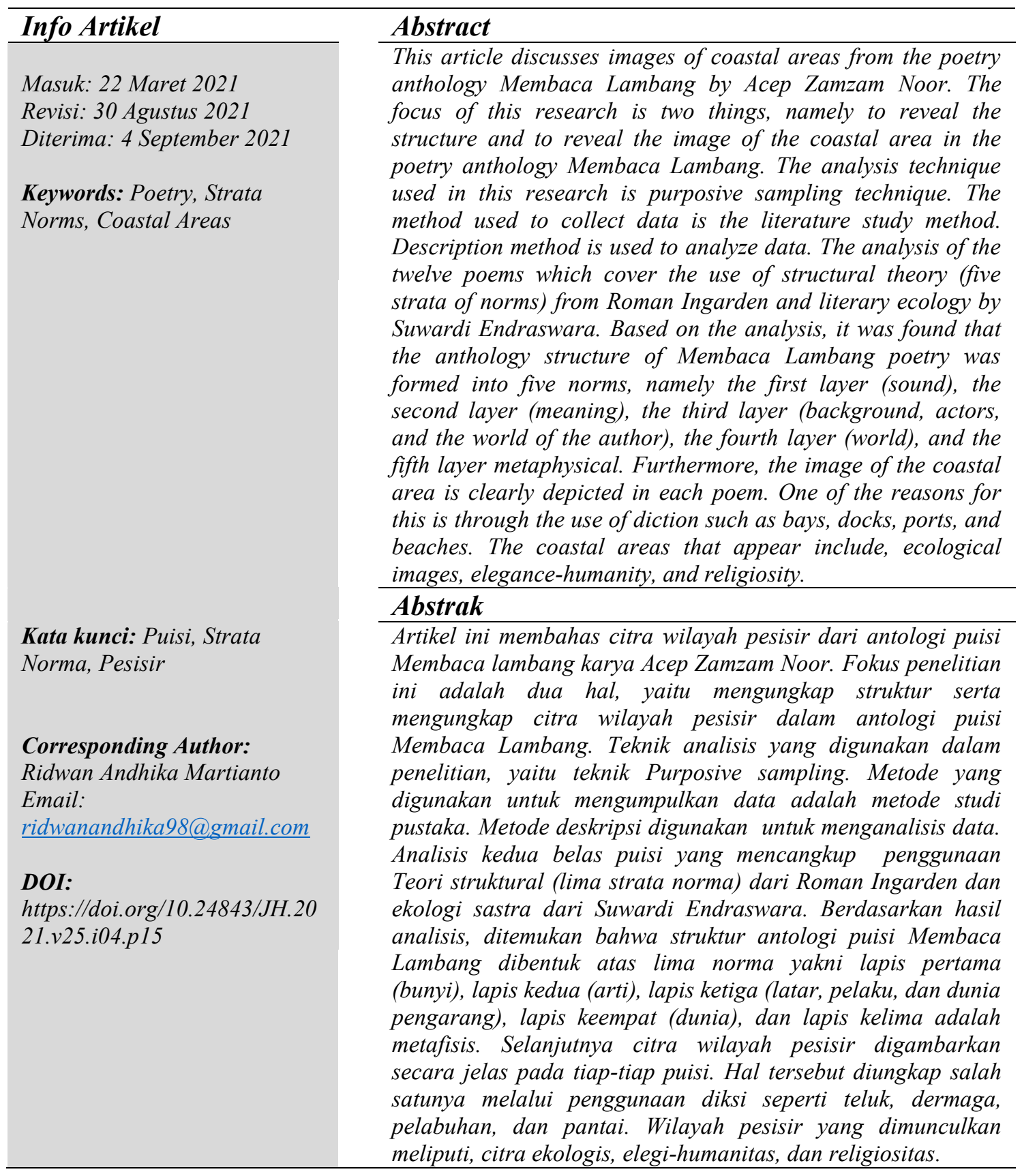




\section{PENDAHULUAN}

Dewasa ini karya sastra yang diciptakan oleh sastrawan semakin memperbanyak pembendaharaan karya sastra, salah satunya dalam bentuk puisi. Puisi merupakan rangkaian kata-kata hasil renungan penulisnya (Susilastri, 2020:90). Oleh sebab itu, dari puisi kenikmatan keindahan, terutama keindahan bahasa, irama, kata-kata, persamaan bunyi, ungkapan kiasan dan citraan (Nurhidayah, 2018: 123).

Sastrawan memiliki kepekaan terhadap hal-hal yang aktual di sekitarnya. Salah satunya adalah nilainilai yang dapat dipelajari dan ditelaah dari alam. Sebab alam memiliki kebermanfaatan dalam kelangsungan hidup manusia (Farida, 2017:48). Sudah sejak lama alam menjadi sumber penciptaan dari berbagai karya sastra. Seringkali alam tidak sekadar menjadi latar cerita dalam karya sastra, tetapi juga dapat menjadi tema utama.

Adanya hubungan antara sastra dan alam memunculkan konsep ekologi sastra. Widianti (2017:3), menyatakan bahwa ekologi sastra adalah ilmu ekstrinsik sastra yang mendalami masalah hubungan sastra dengan lingkunganya. Manshur (dalam Endraswara, 2016:14) mengisyaratkan agar peneliti ekologi sastra untuk memburu tanda-tanda. Gagasan ini dikembangkan demi memecahkan masalah antara sastra dan lingkungan.

Perlu diketahui bahwa sastra dan ekologi merupakan satu kesatuan yang utuh. Berangkat dari ilmu sastra dan ekologi yang saling bertautan maka keduanya akan menjadi pisau bedah dari perspektif ekologi sastra. Seperti terdapat dalam antologi puisi Membaca Lambang karya Acep Zamzam Noor ditemukan kekuatan diksi yang terletak pada citra lingkungan pada setiap daerah.

Antologi puisi Membaca Lambang dijadikan objek penelitian dengan alasan, yaitu (1) antologi ini didominasi oleh dua belas puisi yang mencitrakan wilayah pesisir. Wilayah pesisir adalah suatu wilayah peralihan (interface area) antara ekosistem daratan dan laut (Effendy, 2009: 81); (2) puisi-puisi dengan citra wilayah pesisir memberikan dampak dalam dunia pariwisata. Selain itu terdapat beberapa kritik sosial terhadap perilaku manusia yang sering menjadi faktor utama kerusakan alam terutama di wilayah pesisir. Sebagai negara maritim pengelolaan dan kesadaran manusia akan wilayah pesisir patut digalakkan demi menjaga keselasaran lingkungan.

\section{METODE DAN TEORI}

Metode yang akan digunakan dalam tahapan pengumpulan data adalah metode studi pustaka. Teknik yang digunakan untuk menganalisis data yaitu teknik baca, simak, dan catat. Teknik ini menjadi satu kesatuan yang saling bergantian dilakukan. Cara kerjanya adalah dengan membaca data penelitian dan buku penunjang. Selanjutnya disimak dengan cermat dan diinterpretasi. Kemudian dilakukan proses pencatatan.

Tahapan penyajian hasil analisis data menggunakan metode deskriptif, yaitu dengan penggunaan bahasa Indonesia ragam ilmiah. Hasil analisis data ditulis dalam format skripsi.

Penelitian ini menggunakan teori struktur strata norma yang direkontruksi oleh Roman Ingarden dan teori ekologi sastra oleh Suwardi Endraswara. Kedua teori tersebut menjadi penunjang untuk menganalisis kedua belas puisi dengan citra wilayah pesisir.

\section{Analisis Strata Norma Roman Ingarden}

Sebuah karya sastra dibangun oleh unsur-unsur yang membentuknya. Jadi, kesatuan unsur dalam karya sastra bukan sekadar kumpulan unsur-unsur yang cara pembentukannya saling berdiri sendiri, 
melainkan unsur-unsur itu akan saling berkaitan antara satu dengan lainnya. Analisis struktural Roman Ingarden ini mencangkup kelima lapis norma yaitu; lapis bunyi, lapis arti, lapis ketiga (latar, pelaku, dan dunia pengarang), lapis dunia, dan lapis metafisis.

\section{Lapis Bunyi}

Bunyi dalam puisi merupakan salah satu elemen penting, sebab bunyi puisi dapat dinikmati sebagai orkestra bunyi yang muncul dari kata-kata. Susunan bunyi tersebut dapat dibedah menggunakan konsep aliterasi dan asonanasi.

Asonansi adalah semacam gaya bahasa yang berwujud perulangan bunyi vokal yang sama (Keraf, 2007: 130). Sedangkan, aliterasi dalam (Keraf, 2007:130) adalah semacam gaya bahasa yang berwujud perulangan konsonan yang sama yang digunakan untuk penekanan dan memberi keindahan dalam puisi. Sama halnya dengan pendapat Yunisty dkk. (dalam jurnal Ilmu Bahasa dan Sastra 2020: 396) yang menyatakan bahwa asonansi adalah pengulangan vokal pada satu larik, dan aliterasi adalah pengulangan konsonan.

\section{Lapis Arti}

Selain bunyi yang dapat menciptakan nilai estetika, di dalam sebuah puisi juga terdapat kata, kalimat, dan bait. Elemenelemen tersebut akan menciptakan satukesatuan arti. Pemaknaan arti dalam sebuah puisi tentu memiliki perbedaan oleh setiap pembacanya. Derrida (dalam Adawiyah dan Hasanah, 2019:238) menyatakan bahwa penggunaan bahasa tingkat kedua dalam karya sastra memungkinkan lahirnya penafsiran yang banyak terhadap karya sastra tersebut. (Dewi, Atmaja, dan Triadnyani 2017:60) menyatakan bahwa prinsip dasar sebuah puisi adalah berkata sedikit, tetapi memiliki makna yang luas.

\section{Lapis ketiga}

Lapis satuan arti menimbulkan lapis yang ketiga, lapisan-lapisan ini berupa; latar waktu, latar tempat, pelaku, dan dunia pengarang. Dalam karya sastra latar dan pelaku menjadi unsur penting yang dapat menciptakan kesan bahwa karya sastra dapat menampilkan gambaran kehidupan secara nyata (Pradopo, 1995:18).

\section{Lapis Keempat}

Lapis keempat atau lapis "dunia" yang tidak usah dinyatakan, tetapi sudah implisit. Maksudnya, puisi selain ditulis dengan menggunakan metafor yang ambigu, tidak menutup kemungkinan juga apabila sebuah puisi ditulis dengan implisit, sehingga membuat pembaca dapat memahami maksud puisi meskipun tidak dinyatakan secara gamblang (Pradapo, 1995:18)

\section{Lapis kelima}

Lapis kelima adalah lapis metafisis yang menyebabkan pembaca berkontemplasi (Pradopo, 1995:19). Maksud lain dari pengertian metafisis yaitu lapis norma berupa sifat-sifat metafisis yang bersifat sublim, tragis, suci, mengerikan atau menakutkan (Herlislianti, Surjakusuma, dan Nurjamin, 2018:5).

\section{Ekologi Sastra}

Ekologi dalam karya sastra artinya hubungan timbal balik antara lingkungan dengan makhluknya, dari situ dapat dipahami bahwa memang benar sastra dengan lingkungan tidak bisa dipisahkan satu sama lainnya (Susilo, 2017:2).

Sastra sebagai bidang ilmu menyuguhkan kajian-kajian menarik yang diperoleh dari dunia karya sastra. Ekologi dan sastra dapat berjalan selaras untuk menciptakan permaknaan di dalam sebuah karya sastra. Pandangan ini berangkat dari esensi karya sastra yang merupakan hubungan timbal-balik 
(resiprokal) antara manusia dan lingkungannya. Tidak jarang karya sastra memuat tema-tema ekologis untuk dijadikan "konflik" yang kuat di dalam struktur cerita. Pembicaraan mengenai manusia-lingkungan-Tuhan adalah tema besar kesusastraan baik puisi, prosa, novel, dan drama. Dari hubungan antara Manusia-Tuhan-Lingkungan dapat menciptakan sebuah konsep yang disebut tri hita karana. (Wastika, 2005:75) menyebutkan bahwa tri hita karana yaitu hubungan manusia dengan Tuhan, hubungan manusia dengan manusia, hubungan manusia dengan lingkungannya.

Pembicaraan ekologi sastra dalam pembahasan ini difokuskan pada penjabaran citra yang ditampilkan dalam sajak-sajak Acep. Adapun citra yang ditampilkan adalah wilayah pesisir. Wilayah pesisir merupakan citra yang dominan. Dilihat dari segi kategori terdapat tiga fokus utama wilayah pesisir yakni ekologis, elegi-humanitas, dan religiusitas.

\section{Citra Ekologis}

Citra ekologis merupakan gambaran atau angan yang berhubungan dengan lingkungan. Konsep ekologis dalam dunia sastra, menjadi sebuah objek yang banyak diminati oleh para penulis sastra. Dunia ekologis yang sarat akan efektivitas kosmologis membuat daya tarik tersendiri untuk diangkat ke dalam dunia penciptaan (sastra). Sebagaimana konsep karya sastra yang tidak terlepas dari dunia masyarakat maka munculnya tema-tema ekologi adalah konsekuensi logis dari fakta tersebut.

\section{Citra Elegi-Humanitas}

Citra elegi-humanitas mengarah pada segenap kejadian yang berhubungan dengan kejadian atau fenomena kontekstual ihwal tingkah laku manusia. Elegi adalah istilah umum dalam kesusastraan yang merujuk kepada syair atau nyanyian yang mengandung ratapan dan ungkapan dukacita, khususnya pada peristiwa kematian.

Paul Sorokin (dalam Susanto, 2015: 346) membagi humanisme tiga hal yaitu humanisme ideasional, humanisme idealistik, serta humanisme indrawi.

\section{Citra Religius}

Citra religius menjadi sebuah kajian yang menarik dalam sebuah novel, di dalamnya kita tidak hanya menemukan satu nilai saja, tetapi bermacam-macam nilai yang akan disampaikan oleh pengarangnya, seperti halnya isi karya sastra akan sangat bergantung kepada pengarangnya (Udayana, 2017:220). Begitu pula dalam puisi, nilai-nilai yang terkandung dalam puisi juga tidak terbatas serta berhubungan dengan kehidupan. Kerap kali puisi-puisi lahir dengan pesan rekigiusitas yang kompleks

\section{HASIL DAN PEMBAHASAN}

Hasil dan pembahasan dalam penelitian ini akan diuraikan berdasarkan penelitian yang telah dilakukan.

\section{Analisis Strata Norma Roman Ingarden}

a. Lapis Bunyi

Dari hasil analisis kedua belas puisi karya Acep Zamzam Noor dalam Antologi Puisi Membaca Lambang terdapat adanya asonansi, aliterasi dan pola persajakan. Acep menyisipkan beberapa unsur bunyi tersebut berdasarkan pada pengungkapan perasaan yang ingin disampaikan kepada pembacanya. Seperti terdapat pada puisi 'pelabuhan paotere', ditemukan tujuh asonansi, empat aliterasi. Bunyi yang dominan adalah vokal bersuara $a$ dan $u$ seperti burung, udang, cahaya, kabut, udara, dan perahu. Dari bunyi tersebut terbentuklah beberapa kata yang menjadi 
unsur-unsur di sekitar wilayah pesisir, serta terdapat dua pola persajakan yang menambah keindahan bunyi dalam puisi 'pelabuhan paotere'. Sebagai contoh:
Kematian yang seksi/
Menyelinap
Ke balik sunyi// Seperti burung
Dengan sayap-sayap besi/
Seperti kawat
Yang mengalirkan berahi//.

Selain pada puisi 'pelabuhan paotere' lapis bunyi juga terdapat pada puisi lainnya, yaitu pada puisi 'teluk tomini' terdapat enam asonansi dan tiga pola persajakan dengan bunyi yang paling dominan ialah bunyi vokal $a$ dan $u$ seperti perahu, daun-daun, hutan, dan terumbu. Serta pola persajakan yang terbentuk yaitu:

Terlampau tajam dayungku
merobek dingin
Hingga eranganmu tersangkut gigir
terumbu
Terlampau sakit aku menembus
segala ingin
$\begin{aligned} & \text { Mengayuh waktu mencapai } \\ & \text { marwah rindu }\end{aligned}$

\section{b. Lapis Arti}

Analisis lapis arti pada tiap-tiap puisi antara lain. Puisi 'pelabuhan paotere' menceritakan kekecewaan atas beralih fungsinya pelabuhan Paotere menjadi tempat pariwisata. Sehingga, tidak ditemukan lagi perahu-perahu nelayan sekaligus kapal-kapal pembawa wisatawan. Puisi 'kusamba' menceritakan kehawatiran mengenai dunia yang kian rapuh sehingga sebagai manusia harus tetap waspada. Puisi 'buleleng' menceritakan kisah dari monumen Yudha Mandala sekaligus agar masyarakat dapat mengenang sejarah perjuangan rakyat bali melawan bangsa Belanda. Puisi 'di celukanbawang' menceritakan keprihatinan serta kekecewaan atas rusaknya lingkungan laut di Celukan Bawang, Buleleng. Puisi 'pelabuhan ampenan' menceritakan beralihfungsinya pelabuhan menjadi tempat wisata yang memberikan dampak terhadap para nelayan. Puisi 'anjung cahaya' menceritakan perasaan sepi dan rindu. Puisi 'teluk tomini' menggambarkan suasana di sekeliling Teluk Tomini dengan keindahan serta keasrian yang yang terjaga dengan baik. Selanjutnya puisi 'pantai talise' menggambarkan suasana refleksi kehidupan mengenai hubungan antara manusia dengan Tuhan. Puisi 'benteng kalamata' menceritakan suasana dan gambaran di sekitar Benteng Kalamata. Puspitasari (2020:16-17) menyatakan bahwa Benteng kalamata secara administratif berada di desa Kayu Merah, kecamatan Ternate Selatan, kabupaten Ternate, Provinsi maluku Utara. Benteng Kalamata dikelilingi dinding yang terbuat dari susunan batu endesit dan batu karang. Puisi 'sulamadaha' menggambarkan pencarian Tuhan dalam kehidupan si aku lirik karena Tuhan di dunia memiliki perwujudan yang berbeda-beda. Puisi 'teluk kendari' menggambarkan rasa pasrah dari si aku lirik mengenai kehidupan yang tengah dijalani. Peristiwa-peristiwa yang bersifat duniawi dianggap sebagai cobaan untuk bekal kelak ketika kehidupan telah mati. Puisi 'tapulaga' menggambarkan keprihatinan terhadap peristiwa alam yang tengah terjadi di wilayah Tapulaga yaitu banjir bandang.

c. Lapis ketiga berupa latar, pelaku, dan dunia pengarang

Dalam dua belas puisi yang dianalisis memiliki latar yang berbeda, namun tetap berada pada satu kawasan yaitu wilayah pesisir. Seperti dalam puisi 'pelabuhan paotere' mengambil latar sebuah pelabuhan dengan latar waktu sore hari serta pelaku yang digambarkan 
adalah kamu lirik. Dunia pengarang yang ingin disampaikan yaitu keprihatinan penyair terhadap sebuah pelabuhan yang terasa sangat sepi. Selain puisi 'pelabuhan paotere' terdapat puisi yang mengambil latar tempat yang sama, namun latar waktunya berbeda yaitu puisi 'buleleng'. Pada puisi 'buleleng' latar waktu yang digunakan adalah sore hari, dengan pelaku aku lirik. Dunia pengarang yang ingin disampaikan yaitu mengajak pembaca untuk tetap mengenang dan menghargai jasa pahlawan yang rela berjuang di masa lalu. Di pelabuhan tua ini terdapat sejarah perjuangan rakyat Bali melawan tentara NICA dari Belanda (Astiti, 2018:82).

Selanjutnya, puisi 'benteng kalamata' dan puisi 'tapulaga' keduanya memiliki latar tempat, latar waktu, dan pelaku yang sama, yaitu di dermaga pada siang hari dengan pelaku aku lirik. Dunia pengarang dari puisi 'benteng kalamata' mengisahkan suasana di sekitar benteng serta mengangkat sisi historisnya. Sedangkan, pada puisi 'tapilaga' mengisahkan ketegaran masyarakat Tapulaga dalam menghadapi bencana banjir. Selain puisi 'benteng kalamata' dan 'tapulaga' masih terdapat dua puisi lainnya yang menggunakan latar tempat dermaga, seperti pada puisi 'di celukanbawang' dengan latar waktu abad, dan puisi 'anjung cahaya' dengan latar waktu sore hari. Dunia pengarang pada masing-masing puisi yaitu, 'di celukanbawang' mengisahkan lautan di sekitar PLTU Celukan Bawang yang tercemar dan memberi dampat negative terhadap ekosisitem laut. Pada puisi 'anjung cahaya' kisah perpisahan dari si aku lirik dengan seseorang yang berharga untuknya.

Pada puisi 'kusamba' terdapat latar tempat 'wajahku' yang merujuk pada wilayah di sekitar Kusamba. Disebutkan juga latar waktu malam hari dengan pelaku si aku lirik. Dunia pengarang yang ingin disampaikan yaitu manusia harus tetap waspada terhadap cuaca yang tidak menentu, dan tetap menjaga kelestarian lingkungan lautan agar terjadi keseimbangan alam. Puisi 'pelabuhan ampenan' terdapat beberapa latar tempat seperti jalan, pedestrian, deretan toko, vihara, demaga, pondok-pondok nelayan. Latar waktu yang ditemukan yaitu siang hari dengan pelaku si aku lirik. Lalu, dunia pengarang yang ingin disampaikan yaitu keadaan di sekitar pelabuhan yang mencemaskan setelah beralih fungsinya pelabuhan menjadi tempat wisata yang berdampak terhadap para nelayan. Di samping itu juga keadaan di Pelabuhan menjadi sepi.

Selain latar pelabuhan, dermaga, ditemukan juga latar tempat pantai yang terdapat pada puisi 'pantai talise' dan 'sulamadaha'. Latar waktu, pelaku, dan dunia pengarang pada masing-masing puisi secara berurutan. Pada puisi 'pantai talise' disebutkan latar waktu pagi hari dengan pelaku aku lirik, dunia pengarang yang ingin disampaikan yaitu lautan yang menjadi salah satu ciptaan Tuhan seharusnya dapat membuat manusia ingat akan kebesaran Tuhan. Sehingga sebagai makhluk hidup manusia dapat menghargai serta bersyukur berkat nikmat yang telah diberikan. Pada puisi 'sulamada' terdapat latar waktu pagi hari dengan pelaku aku lirik. Dunia pengarang yang ingin disampaikan yaitu lingkungan yang masih terjaga dan asri menjadi salah satu bagaimana seseorang memahami sempurnanya ciptaan Tuhan. Alam lah yang membuat makhluk di bumi dapat hidup dengan segala sumber dayanya. Dengan ini penyair ingin menyadarkan manusia untuk selalu menjaga lingkungan dengan caranya masing-masing. Sebab, manusia bertanggung jawab terhadap keberlanjutan ekosistem karena manusia disiptakan sebagai khalifah (Nahdi, 2008:159-172). 
Selanjutnya puisi 'teluk tomini' ditemukan latar tempat lautan, dengan latar waktu siang hari. Pelaku pada puisi 'teluk tomini' adalah aku lirik dan kamu lirik, dengan dunia pengarang yang ingin disampaikan yaitu keindahan alam di Teluk Tomini menjadi salah satu contoh keasrian ekosisitem laut, sehingga sebagai manusia harus turut serta menjaga dan melestarikan ekosisitem lingkungan. Pada puisi 'teluk kendari' mengambil latar tempat sebuah teluk dengan latar waktu pagi hari dan pelaku aku lirik. Dunia pengarang yang ingin disampaikan yaitu hubungan timbal balik antara alam dan makhluk hidup tentu tidak dapat dipisahkan, alam yang terjaga ekosistemnya akan lebih memberikan dampak positif kepada makhluk di sekitarnya begitu juga sebaliknya.

\section{d. Lapis Keempat}

Lapis keempat atau lapis 'dunia' yang dipandang dari sudut pandang tertentu yang tidak perlu dinyatakan , tetapi sudah implisit. Seperti terdapat pada dua belas puisi dalam antologi Membaca Lambang. Berikut pemaparan lapis 'dunia' pada puisi 'pelabuhan paotere' yaitu dari sudut pandang tertentu, pada bait pertama baris satu sampai lima menyatakan bahwa waktu pagi hari dengan cahayanya yang terlihat seolah-olah mewarnai langit, dengan aroma pagi yang tercium sampai di pelabuhan. Bait kedua baris satu dan dua menyatakan tidak adanya aktivitas lain di pelabuhan selain orang-orang yang memburu udang. Dilanjutkan bait ketiga dapat ditemukan pada baris kesatu sampai ketiga yang menggambarkan perahu-perahu sudah tidak ada yang bersandar di pelabuhan.

Pada bait keempat baris kelima terdapat diksi "gambar badik". Badik sendiri memiliki kekuatan sakti yang dapat memengaruhi segala proses kehidupan untuk menjadi lebih baik atau menjadi lebih buruk. Sedangkan pada bait kelima baris kesatu dan kedua yang maksudnya kisah dari pelabuhan itu hanya menunjukkan dinamika kehidupan yang tidak beragam. Dilanjutkan pada bait keenam bait kelima dan keenam menggambarkan sebuah tempat yang terlihat antara berfungsi dan tidak berfungsi. Selanjutnya bait kesembilan baris kesatu dan dua menyatakan kisah dari pelabuhan Paotere hanya menyisakan sedikit waktu untuk bertahan.

Selain puisi 'pelabuhan paotere' akan dipaparkan juga analisis pada puisi 'teluk tomini' yaitu, Dipandang dari sudut pandang tertentu, bait pertama baris kesatu dan dua menyatakan si aku lirik yang terlanjur akrab dan dekat dengan tokoh mu yang dianalogikan sebagai teluk tomini. Bait kedua baris pertama sampai ketiga menyatakan perasaan bahagia dari si aku lirik ketika menikmati pemandangan di teluk. Dilanjut pada bait keempat baris pertama menyatakan gambaran jelas mengenai teluk tomini tersebut yang di kelilingi oleh deretan bukit.

\section{e. Lapis Kelima}

Lapis kelima atau lapis metafisis membedah puisi-puisi yang memberikan kontemplasi/perenungan terhadap peristiwa sublim, tragis dan suci. Seperti pada puisi 'pelabuhan paotere' memberi gambaran tragis sebuah pelabuhan yang secara fungsi dipergunakan sebagai transaksi jual beli ikan serta bongkar muat kapal-kapal pembawa ikan kini dijadikan tempat pariwisata. Sehingga menimbulkan dampak yang kurang baik bagi nelayan di sekitar pelabuhan. Selain itu, dampak lain juga dirasakan oleh pedagang kaki lima (Pratiwi dkk, 2020:164) menyatakan bahwa perkembangan pedagang kaki lima hingga saat ini sudah mulai terjadi penurunan pendapatan dan bahkan ada 
yang sudah mulai beralih profesi dengan mencari usaha sampingan untuk menutupi kebutuhan hidupnya. Sehingga, dapat dikatakan keberadaan pedagang kaki lima di pelabuhan Paotere sudah mulai hilang eksistensinya.

Selanjutnya pada puisi 'teluk tomini' terdapat lapis metafisis yang mengarah pada keindahan sebuah Teluk Tomini. Teluk Tomini merupakan teluk yang berada di Pulau Sulawesi, Indonesia dan mendapat penobatan sebagai teluk terbesar di Indonesia. Selain itu, Teluk Tomini juga berperan penting bagi dunia karena letaknya yang berada di garis khatulistiwa dan memiliki ekosisitem laut semi tertutup. Sumber daya yang dapat ditemukan dari Teluk Tomini antara lain; terumbu karang endemik, hamparan hutan mangrove, serta sumber daya pesisir yang melimpah.

Pada puisi 'pantai talise' terdapat lapis metafisis yang mengarah pada sifat suci yaitu Manusia sebagai makhluk yang diciptakan dengan akal dan pikiran yang sepurna tentu patut beriman sesuai dengan kepercayaannya. Rasa syukur terhadap Tuhan yang menciptakan dunia beserta isinya menjadi salah satu kewajiban agar sebagai manusia tidak memiliki sifat jemawa. Pada puisi 'pantai talise' digambarkan bahwa ketika si aku lirik memandang pantai terasa Tuhan telah memberi banyak kenikmatan kepadanya, sehingga si aku lirik dapat menikmati pantai pada masa hidupnya.

\section{Citra Ekologis}

Citra ekologis merupakan gambaran atau angan yang berhubungan dengan lingkungan. Citra ekologis menurut Eliot mengacu ke pedalaman perasaan yang tidak dapat kita lihat, "may have symbolic value, but of waht we cannot tell, for they have come to represent the depths of feeling into which we cannot peer" (dalam Wellek, 2014:85). Fokus analisis Antologi Puisi Membaca
Lambang ini lebih mengarah ke analisis citra ekologis yang menunjukkan kerusakan alam, ditunjukkan dalam metafor sebagai berikut. Pelabuhan Paotere /kisahmu tinggal jejak kaki para pemburu udang/, Kusamba /cahaya yang terbit hanya menerangi sebelah hatiku/, Di Celukanbawang /kau sudah lama mati/, Pelabuhan Ampenan /perahuperahu membisu, juga tiang-tiang kayu. Bentangan tambang serta beberapa nelayan mda yang nampak termangu/, Teluk Kendari /kekasihku, jika suatu saat pulau-pulau menenggelamkan diri/, dan Tapulaga /sebuah pondok tampak seperti bangkai perahu di tengah laut/.

\section{Citra Elegi-Humanitas}

Citra elegi-humanitas dalam antologi puisi Membaca Lambang terdapat dalam sajak Buleleng, Anjung Cahaya, Teluk Tomini dan Benteng Kalamata. Lalu dari keempat puisi di atas lebih mengarah pada humanisme Indrawi. Dapat dibuktikan dari metafora tiap-tiap puisi. Seperti, Buleleng laku berdiri sepanjang senja di pelabuhan tua/, Anjung Cahaya laku melihat sampan meninggalkanku/, teluk tomini /kurengkuh ombakmu dengan kedua lengan/,"benteng kalamata" /bilah-bilah batu bercerita padaku lewat kilau cahaya perak yang diterimanya dari matahari/.

\section{Citra Religiusitas}

Dalam kedua sajak dengan judul Pantai Talise dan Sulamadaha menunjukkan sisi religiositas dalam baitbaitnya. Sebagai bukti berikut penulis sertakan gambaran religiusitasnya. Dalam puisi Pantai Talise terdapat dalam bait ketiga:

Sekian lama aku menunggu suaramu turun menemui kami

Di bumi.Sekian lama aku membayangkan pertemuan gaib itu

Ketika sabda dan gema berkelindan bagai garam dengan lautan 
Makna dari kutipan bait di atas ialah keinginan dari si aku lirik terhadap suarasuara yang benar-benar suci ke bumi, sebab adanya perbedaan keyakinan, serta seseorang yang mengaku sebagai "Tuhan". Sedangkan menurut ajaran Islam, Nabi dipandang sebagai orang yang paling otoritatif (paling berwenang), memiliki persyaratan yang dapat dipercaya, untuk menafsirkan semua kehendak Allah (Khaldun, 2012:115) Tokoh si aku lirik mengharapkan sebuah pertemuan dalam doa-doanya dengan sosok Tuhan sehingga ia dapat merasakan sendiri ilham yang dapat menuntun si aku lirik dalam menjalankan kehidupan.

Selanjutnya, dalam puisi 'Sulamadaha' terdapat dalam bait kedua baris kedua dan ketiga dan bait keempat yaitu:

Satu lukisan tak akan habis ditafsir sepanjang putaran waktu

Dan setiap tafsir akan melahirkan sejumlah pemaknaan lain

Lukisan yang diibaratkan sebagai sosok "Tuhan" menyimbolkan kehidupan manusia sesekali sering menafsirkan bentuk serta wujud dari Tuhan. Akan tetapi, saking berilmunya manusia dan memiliki daya tafsir masing-masing sehingga mengakibatkan penafsiran yang tidak selaras antara satu dengan yang lain. Hal ini, memberikan sebuah permasalahan di tatanan masyarakat, seperti intoleransi dan sikap-sikap diskriminasi terhadap sesama manusia.

Beranjak dari ketiga citra tersebut, secara garis besar dapat ditarik kesimpulan bahwa citra wilayah pesisir yang digambarkan dari kedua belas puisi saling berkaitan erat dengan ekologis, religiositas, dan humanitas. Pembuktian ihwal fakta tersebut diperoleh dari pengalaman penyair yang tidak lepas dari lingkungan di sekelilingnya. Citra ekologis, religiositas, dan humanitas saling mendukung satu dengan lain. Hubungan ketiga hal tersebut dibangun atas dasar struktur wilayah pesisir yang kuat.

\section{SIMPULAN}

Lapis bunyi yang ditemukan di kedua belas puisi yaitu asonansi, aliterasi, dan pola persajakan. Ketiga lapis bunyi tersebut yang mendominasi adalah asonansi /a/dan $/ u /$. Lapis arti dari kedua belas puisi tersebut menceritakan kerusakan alam, kekecewaan, kekhawatiran, sejarah, religus, dan kecemasan. Latar dalam kedua belas puisi mengarah kepada latar yang berada di wilayah pesisir. Sedangkan dunia pengarang mengarah terhadap bagaimana Acep menceritakan wilayah pesisir dengan gambaran kisah-kisah yang didapatnya ketika berada di wilayah tersebut. Lapis keempat atau lapis 'dunia' pada tiap-tiap puisi memiliki gambaran yang berbeda-beda. Lapis metafisis membedah sifat-sifat dari puisi berupa sifat sublim, tragis, dan suci.

Analisis ekologis terhadap citra wilayah pesisir berhasil membongkar citra yang terdapat dalam kedua belas puisi yaitu citra ekologis, citra humanis, dan citra religius. Citra ekologis adalah gambaran atau angan yang berhubungan dengan lingkungan, citra ekologis yang ditemukan yaitu citra kerusakan alam yang terdapat dalam puisi Pelabuhan Paotere, Kusamba, Di Celukanbawang, Pelabuhan Ampenan, Teluk Kendari, dan Tapulaga.

Citra elegi-humanitas yaitu citra yang mengarah pada segenap kejadian yang berhubungan dengan kejadian atau fenomena kontekstual ihwal tingkah laku manusia. Citra elegi-humanitas sendiri memiliki tiga jenis yaitu humanisme ideasional, humanisme idealistik, serta humanisme indrawi. Citra humanitas yang ditemukan terdapat pada Buleleng, Anjung Cahaya, Teluk Tomini, dan 
Benteng Kalamata. Selanjutnya citra religusitas terdapat dalam puisi pantai talise dan sulamadaha.

Rekomendasi untuk penelitian berikutnya diharapkan dapat mengkaji kembali lebih dalam dari segi hubungan antar makhluk hidup yang terdapat pada antologi puisi Membaca Lambang.

\section{REFERENSI}

Adawiyah, R., \& Hasanah, M. (2019). Stereotip Perempuan dalam Novel di Balik Kerling Saatirah Karya Ninik M. Kuntarto: Kajian Dekonstruksi Jacques Derrida. BASINDO: jurnal kajian bahasa, sastra Indonesia, dan pembelajarannya, 3(2).

Astiti, I. K. A. (2018). Optimalisasi Pengelolaan Pelabuhan-Pelabuhan Kuno Di Buleleng Dalam Pengembangan Pariwisata. In Forum Arkeologi 31(1).

Dewi, E. P. S., Atmaja, M. J., \& Triadnyani, I. G. M. Citra Pantai Bali dalam Antologi Puisi Impian Usai Karya Wayan Sunarta: Kajian Semiotik. Humanis, 19(1).

Efendy, M. (2009). Pengelolaan Wilayah Pesisir Secara Terpadu: Solusi Pemanfaatan Ruang, Pemanfaatan Sumberdaya Dan Pemanfaatan Kapasitas Asimilasi Wilayah Pesisir Yang Optimal Dan Berkelanjutan. Jurnal Kelautan: Indonesian Journal of Marine Science and Technology, 2(1).

Endraswara, Suwardi. 2016. Metodologi Penelitian Ekologi Sastra. Yogyakarta:CAPS (Center For Academic Publishing Service).

Farida, D. N. (2017). Kritik ekologi sastra puisi perempuan lereng gunung karya Ika Permata hati dalam antologi puisi perempuan di ujung senja melalui ekofeminisme Susan Griffin. BASINDO: jurnal kajian bahasa, sastra Indonesia, dan pembelajarannya, 1(2).

Herlislianti, E., Surjakusuma, Y., \& Nurjamin, A. (2018). Lapis Norma dan Pengalaman Jiwa Puisi-Puisi Maman S. Mahayana dalam Antologi Jejak Seoul. Lingua Sastra, 1(1).

Keraf, Gorys. 2007. Diksi dan Gaya Bahasa. Jakarta: PT Gramedia Pustaka Utama

Khaldun, R. (2012). Hermeneutika Khaled Abou El Fadl: Sebuah Upaya Untuk Menemukan Makna Petunjuk Kehendak Tuhan Dalam Teks Agama. Jurnal EduIslamika, 3(1).

Nahdi, M. S. (2008). Konservasi Ekosistem dan Keanekaragaman Hayati Hutan Tropis Berbasis Masyarakat. Jurnal Kaunia, 4(2).

Pradopo, Rahmat Joko. 1995. Pengkajian puisi : analisis strata norma dan analisis struktural dan semiotik. Yogyakarta:Gadjah Mada University Press.

Puspitasari, A., \& Maryam, M. (2021). Keunikan Tiga Benteng Kalamata, Benteng Rotterdam dan Benteng Malborough (Tinjauan berdasarkan sejarah pembuatannya). Tsaqofah dan Tarikh: Jurnal Kebudayaan dan Sejarah Islam, 5(2).

Susanto,Dwi. 2015. Kamus Istilah Sastra. Yogyakarta: Pustaka Pelajar 
Susilastri, D. (2020). Strata Norma Roman Ingarden dalam Apresiasi Puisi. JSSH (Jurnal Sains Sosial dan Humaniora), 4(2).

Susilo, R. (2017). Kajian Ekologi Sastra Cinta Semanis Racun 99 Cerita dari 9 Penjuru Dunia Terjemahan Anton Kurnia. Jurnal Nosi, 5(5).

Udayana, H., \& Indiatmoko, B. (2017). Ekspresi Cinta dan Citra Religius dalam Novel Atheis Karya Achdiat Kartamihardja. Seloka: Jurnal Pendidikan Bahasa dan Sastra Indonesia, 6(2).

Wastika, D. N. (2005). Penerapan konsep tri hita karana dalam perencanaan perumahan di Bali. Jurnal Permukiman Natah, 3(2).

Wellek, Rene dan Austin Werren. 2014. Teori Kesusastraan. Diterjemakan oleh Melani Budianta. Jakarta: PT Gramedia Pustaka Utama.

Widianti, A. W. (2017). Kajian Ekologi Sastra Dalam Kumpulan Cerpen Pilihan Kompas 2014 Di Tubuh Tarra Dalam Rahim Pohon. DIKSATRASIA, 1(2).

Yunisty, I. P., Hayana, N., \& Mutiarsih, Y. Gaya Bahasa Asonansi dan Aliterasi pada Antologi Puisi Romances Sans Paroles. Nusa: Jurnal Ilmu Bahasa dan Sastra, 15(3). 